\title{
Effects of Added Chloride Ion on Electrodeposition of Copper from a Simulated Acidic Sulfate Bath Containing Cobalt Ions
}

\author{
Bijayalaxmi Panda \\ Amity School of Engineering and Technology, Amity University, Noida, Uttar Pradesh 201303, India \\ Correspondence should be addressed to Bijayalaxmi Panda; blpanda@amity.edu
}

Received 14 November 2012; Accepted 18 December 2012

Academic Editors: M. Carboneras, M. Gjoka, and S. C. Wang

Copyright ( 2013 Bijayalaxmi Panda. This is an open access article distributed under the Creative Commons Attribution License, which permits unrestricted use, distribution, and reproduction in any medium, provided the original work is properly cited.

\begin{abstract}
The effects of added chloride ion on copper electrodeposition was studied using $\mathrm{Pb}$-Sb anode and a stainless steel cathode in an acidic sulfate bath containing added $\mathrm{Co}^{2+}$ ion. The presence of added chloride ion in the electrolyte solution containing $150 \mathrm{ppm}$ of $\mathrm{Co}^{2+}$ ion was found to increase the anode and the cell potentials and decrease the cathode potential. Linear sweep voltammetry (LSV) was used to study the effects of added chloride ion on the anodic process during the electrodeposition of copper in the presence of added $\mathrm{Co}^{2+} \approx 150 \mathrm{ppm}$; the oxygen evolution potential is polarised by adding $10 \mathrm{ppm}$ chloride ion at current densities $\left(\geq 150 \mathrm{~A} / \mathrm{m}^{2}\right)$, and further increase in chloride ion concentration increases the polarisation of oxygen evolution reaction more at higher current densities. X-ray diffraction (XRD) showed that added chloride ion and added $\mathrm{Co}^{2+}$ ion changed the preferred crystal orientations of the copper deposits differently. Scanning electron microscopy (SEM) indicated that the surface morphology of the copper deposited in the presence of added chloride ion and added $\mathrm{Co}^{2+}$ ion has well-defined grains.
\end{abstract}

\section{Introduction}

Copper is generally extracted through pyrometallurgical processes [1]. However several important factors such as nonavailability/depletion of high-grade ores, increasing world demand, increasing process cost like labour cost, energy cost, and so forth, and emission of highly toxic and strongly acidic sulfur-oxide gases from smelter plants creating severe environmental pollution demanded an alternative technology to overcome these problems towards the end of nineteenth century. Thus in mid of 1980, hydrometallurgical processes involving leaching, solvent extraction, and electrowinning (L/SX/EW) were widely adopted for extraction of copper from secondary sources such as oxide ores, mixed sulfide and oxide ores, low grade sulfide ores, industrial wastes from metal plating, metal finishing, wastes from metallurgical industries, scrap copper, and alloys [1]. Although copper leaching and solvent extraction have achieved a state of advanced development, the commercial success of the process is dependent upon the ability to produce high-quality final product through the electrowinning process. The high power consumption associated with this process has been the subject of many investigations in the last few years [2-6]. The attempts made so far are [7]

(a) improvement in mass transport for cell operation at higher-current density without significant increase in energy requirement,

(b) selection of different routes for production of the copper metal,

(c) adoption of an alternative anode reaction,

(d) use of inorganic and organic depolarisers for decreasing the overpotential of oxygen evolution reaction at the anode and copper deposition reaction at the cathode,

(e) replacement of the $\mathrm{Pb}-\mathrm{Sb}$ anode by a catalytic anode for decreasing the oxygen overpotential and many similar aspects.

In recent years, a more challenging problem is the efficient recovery of copper through electrodeposition process from the direct acidic leach solution and dilute industrial effluents with low power consumption $[8,9]$ eliminating SX process 
that involves alot of chemicals. The attempts described in (c)-(e) above are of particular interest as these that will be amenable to industrial implementation without any significant change in the standard plant practice. These attempts could bring significant decrease in cell voltage and power consumption through lessening of the anode potential or anode overpotential. Bivalent cobalt ion is a very useful addendum in copper electrodeposition [10-12] due to the following reasons.

(a) It considerably decreases the overpotential of oxygen evolution reaction.

(b) It significantly controls the lead corrosion of the lead-antimony anode and subsequently improves the cathode quality by reducing lead contamination.

(c) It can be used in conventional copper electrodeposition process without any modification to the existing plant cell.

Our earlier investigations [5, 12] reported the effects of cobalt ion and/or $\mathrm{H}_{2} \mathrm{SO}_{3}$ on copper electrodeposition from simulated acidic sulfate bath using $\mathrm{Pb}-\mathrm{Sb}$ and/or graphite anode with significant decrease in power consumption.

In the present investigation, an attempt is made to see the effects of added $\mathrm{Cl}^{-}$ion on the electrodeposition of copper from a simulated acidic copper bath containing added $\mathrm{Co}^{2+}$ ion. Small amounts of chloride ion alone are known to have an accelerating effect on the deposition of copper and reduces anode polarization [13]. Besides, $\mathrm{Cl}^{-}$ion arises in the copper electrolyte from the makeup water. Several studies were undertaken to observe the effect of $\mathrm{Cl}^{-}$ion on electrodeposition of copper [13-19] including the interaction of $\mathrm{Cl}^{-}$ion with some entrained extractant residuals [20]. However, no literature appears to be available so far to our knowledge on the effect of $\mathrm{Cl}^{-}$ion on electrodeposition of copper containing $\mathrm{Co}^{2+}$ ion. $\mathrm{Pd} / \mathrm{Sb}$ is used as an anode material. A comparison of cell potential, anode potential, cathode potential, anode polarization characteristics, current efficiency, power consumption, deposit quality, deposit morphology, and the crystal orientation is reported in the absence and the presence of $\mathrm{Cl}^{-}$during electrodeposition of copper in the presence of $\mathrm{Co}^{2+}$ ion.

\section{Experimental Methods}

2.1. Materials. Stock solutions of $40 \mathrm{~g} / \mathrm{L} \mathrm{Cu}^{2+}, 10 \mathrm{~g} / \mathrm{L} \mathrm{Co}^{2+}$ and $60 \mathrm{~g} / \mathrm{L}$ sulfuric acid, and $10 \mathrm{~g} / \mathrm{L} \mathrm{HCl}$ were prepared separately using AnalaR grade reagents in doubly distilled water. The concentration of $\mathrm{Cu}^{2+}$ was measured by iodometric method, while $\mathrm{H}_{2} \mathrm{SO}_{4}$ was determined by acid-base titration, $\mathrm{Co}^{2+}$ by atomic absorption spectroscopy (Model 3100, PerkinElmer) and $\mathrm{Cl}^{-}$by EDT (England ion meter).

2.2. Electrodeposition Experiments. The electrolysis cell consisted of a lidded $200 \mathrm{~cm}^{3}$ double wall beaker. A stainless steel cathode $(8.0 \times 5.0 \times 0.2 \mathrm{~cm})$ and a lead-antimony $(\mathrm{Sb}=6 \%)$ anode of the same dimensions were used. The interelectrode space was maintained at $3.0 \mathrm{~cm}$ for all the experiments.
All electrodeposition experiments were carried out for 2 hours at room temperature $\left(30 \pm 1^{\circ} \mathrm{C}\right)$ using an electrolyte solution containing $20 \mathrm{~g} / \mathrm{L} \mathrm{Cu}^{2+}$ and $30 \mathrm{~g} / \mathrm{L} \mathrm{H}_{2} \mathrm{SO}_{4}$, and $150 \mathrm{ppm} \mathrm{Co}^{2+}$ ion. After electrolysis, the cathode was washed thoroughly with water followed by acetone and dried. The current efficiency $( \pm 0.3 \%)$ was calculated from the weight of copper gained by the cathode. The electrodeposited copper was analysed as $>99.9 \%$ pure.

2.3. Polarisation Measurements. Linear sweep voltammetry (LSV) was used to examine the anodic polarisation behaviour, during copper electrodeposition containing added $\mathrm{Cl}^{-}$and/or added $\mathrm{Co}^{2+}$. $\mathrm{A} \mathrm{Pb}-\mathrm{Sb}\left(0.70 \mathrm{~cm}^{2}\right)$ electrode was used as the working anodic electrode. A platinum wire and a saturated calomel electrode (SCE) were used as the counter electrode and the reference electrode, respectively. The surface of the working electrode was freshly prepared before each experiment, initially rinsed with 1M HCL followed by doubly distilled water. A scanning potentiostat (Model 362, EG\&G Princeton Applied Research) was used for carrying out polarisation experiments between $+1.2 \mathrm{~V}$ and $+2.0 \mathrm{~V}$. The linear voltammograms $(\mathrm{V} \sim \mathrm{I})$ were recorded by using an $X-Y$ recorder (PAR Model RE0091, EG\&G Princeton Applied Research) at a scan rate of $20 \mathrm{mV} / \mathrm{sec}$ during polarisation experiments.

2.4. Deposit Examination. An X-ray diffractometer (PW 1050, Philips) was used to determine the crystallographic orientations of the cathode copper deposits. Reproducible results were obtained using cathode-deposited sections and powders scraped from the cathode surface. The data matched those for copper powders reported in the literature (JCPDS, 1984). The deposit morphology of the electrodeposited copper samples was examined by SEM (SE 101B model, Philips).

\section{Results and Discussion}

3.1. Anode Potential. Effect of Added Chloride Ion Variation in the Presence of Added Cobalt Ion. The influence of $\left[\mathrm{Cl}^{-}\right]_{\mathrm{o}}$ on the anode voltage in the presence of $\left[\mathrm{Co}^{2+}\right]_{0} \cong 150 \mathrm{ppm}$ in the electrolyte solution is shown in Figure 1. The anode voltage in the absence of $\mathrm{Cl}^{-}$ion in the electrolyte containing only $\mathrm{Co}^{2+}(\mathrm{aq})(\cong 150 \mathrm{ppm})$ is found to be $1.58 \mathrm{~V}$. Addition of $5 \mathrm{ppm}$ of $\mathrm{Cl}^{-}$ion to the same electrolyte increases the anode voltage to $1.63 \mathrm{~V}$. No significant increase in the anode potentials is observed with further increase in $\left[\mathrm{Cl}^{-}\right]_{\mathrm{o}}$ up to 100 ppm.

3.2. Cathode Potential. Effect of Added Chloride Ion Variation in the Presence of Cobalt Ion. The cathode potential at zero concentration of $\mathrm{Cl}^{-}$in the electrolyte containing $\mathrm{Co}^{2+}$ (aq) $\cong 150 \mathrm{ppm}$ was found to be $0.25 \mathrm{~V}$. The addition of $\left[\mathrm{Cl}^{-}\right]_{\mathrm{o}} \cong$ $5 \mathrm{ppm}$ decreases the cathode potential from 0.25 to $0.19 \mathrm{~V}$. Further increase in $\left[\mathrm{Cl}^{-}\right]_{0} \cong 100 \mathrm{ppm}$ brings about no significant change in the cathode voltage in the presence of $\left[\mathrm{Co}^{2+} \text {.aq }\right]_{\mathrm{o}} \cong 150 \mathrm{ppm}$ as observed in Figure 2 . 


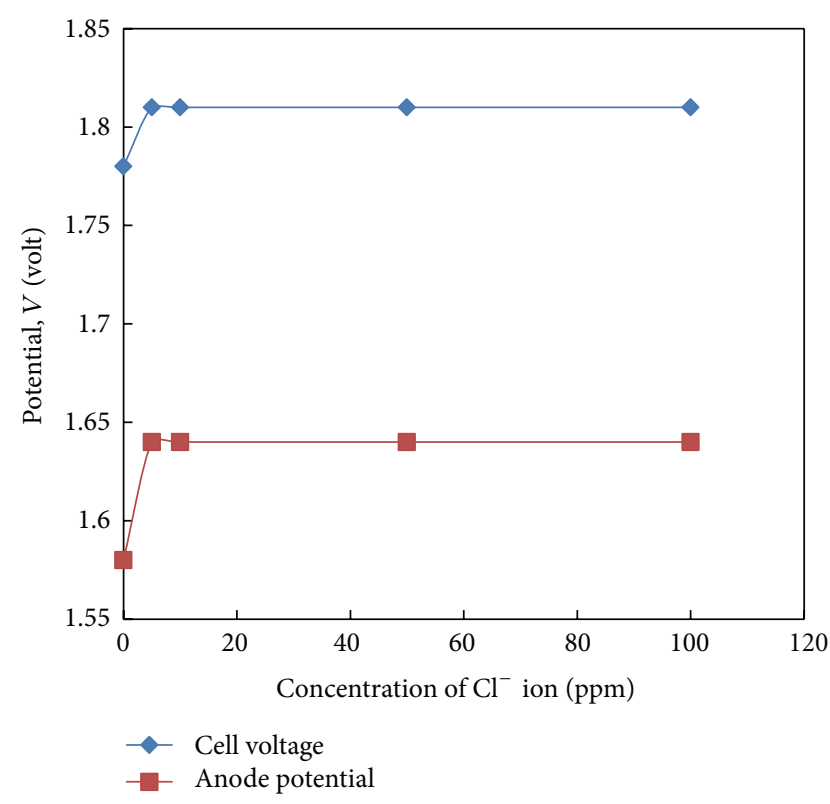

Figure 1: Effect of added $\left[\mathrm{Cl}^{-}\right]_{0}$ on cell voltage and anode potential in the presence of added cobalt ion $150 \mathrm{ppm}\left(\mathrm{Cu}^{2+}=20 \mathrm{~g} / \mathrm{L}, \mathrm{H}_{2} \mathrm{SO}_{4}\right.$ $\left.=30 \mathrm{~g} / \mathrm{L}, T=30 \pm 1^{\circ} \mathrm{C}, \mathrm{CD}=150 \mathrm{~A} / \mathrm{m}^{2}, t_{d}=2 \mathrm{hr}\right)$.

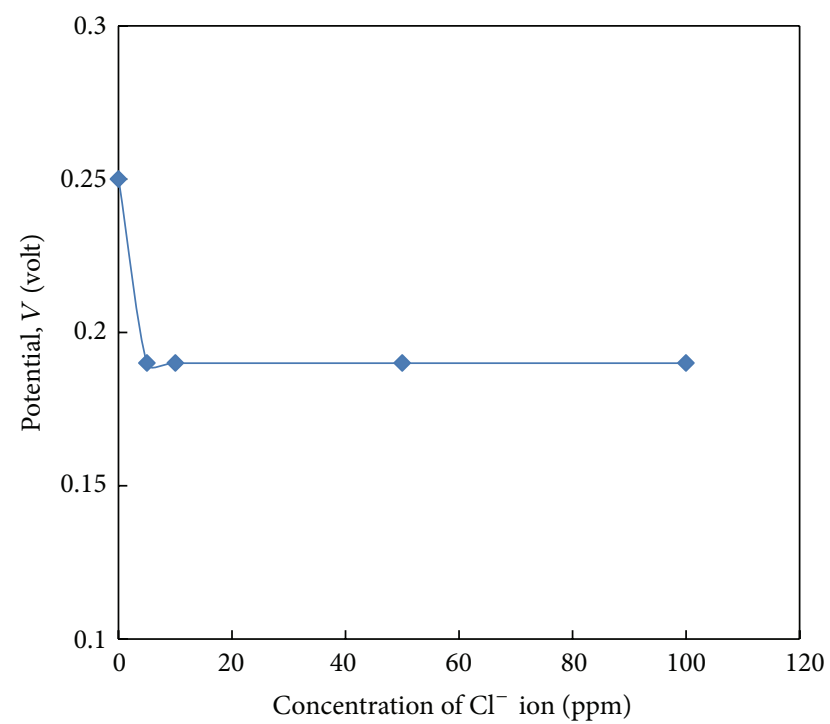

FIGURE 2: Effect of $\left[\mathrm{Cl}^{-}\right]_{\mathrm{o}}$ on cathode potential in the presence of added cobalt ion $150 \mathrm{ppm}\left(\mathrm{Cu}^{2+}=20 \mathrm{~g} / \mathrm{L}, \mathrm{H}_{2} \mathrm{SO}_{4}=30 \mathrm{~g} / \mathrm{L}, \mathrm{T}=30 \pm\right.$ $\left.1^{\circ} \mathrm{C}, \mathrm{CD}=150 \mathrm{~A} / \mathrm{m}^{2}, t_{d}=2 \mathrm{hr}\right)$.

3.3. Cell Voltage. Effect of Added Chloride Ion Variation in the Presence of Cobalt Ion. Figure 1 shows the influence of $\left[\mathrm{Cl}^{-}\right]_{0}$ on cell voltage in the presence of added $\mathrm{Co}^{2+}(\mathrm{aq})$ during electrodeposition of copper. The nature of the curve appears to be similar to that observed in the case of the anode potential. Addition of $5 \mathrm{ppm}$ of $\mathrm{Cl}^{-}$to the same electrolyte increases the cell voltage to $1.81 \mathrm{~V}$. Further increase in $\left[\mathrm{Cl}^{-}\right]_{\mathrm{o}}$ in the range of 5-100 ppm brings about no significant increase in the cell voltage.

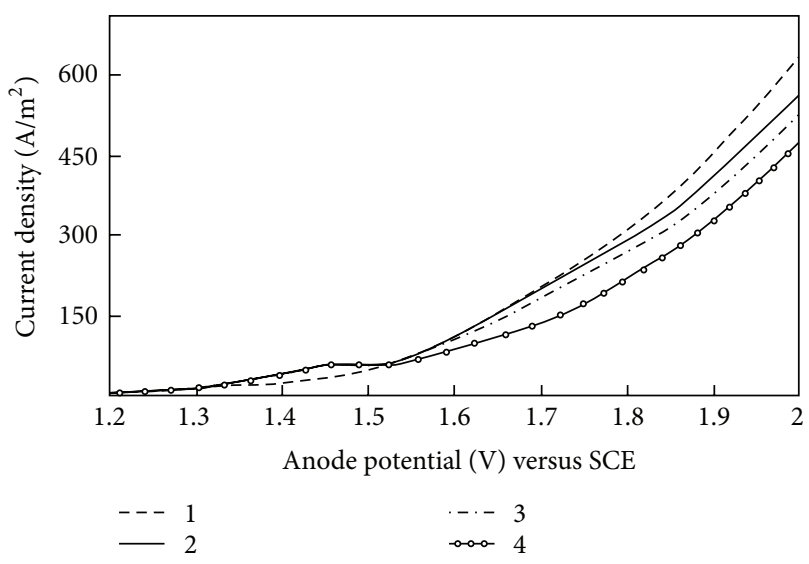

FIGURE 3: Anodic potentiodynamic curves in the presence of added chloride ion. Key: added $\left[\mathrm{Cl}^{-} \text {. aq }\right]_{\mathrm{o}}$ (1) nil; (2) $5 \mathrm{ppm}$; (3) $50 \mathrm{ppm}$; (4) $100 \mathrm{ppm}\left(\mathrm{Cu}^{2+}=20 \mathrm{~g} / \mathrm{L}, \mathrm{H}_{2} \mathrm{SO}_{4}=30 \mathrm{~g} / \mathrm{L},\left[\mathrm{Co}^{2+}\right]_{\mathrm{o}}=150 \mathrm{ppm}\right.$ $T=30 \pm 1^{\circ} \mathrm{C}$, scan rate $\left.20 \mathrm{mV} / \mathrm{Sec}\right)$.

3.4. Anode Polarisation. The anodic potentiodynamic experiments conducted by varying the chloride ion concentration in the presence of $\left[\mathrm{Co}^{2+}\right]_{0} \cong 150 \mathrm{ppm}$ in the copper electrolyte solution were studied by LSV method, and the curves are shown in Figure 3. Figure 3 curve 1 shows current density versus anode potential curve in the presence of $\left[\mathrm{Co}^{2+}\right]_{\mathrm{o}} \cong 150 \mathrm{ppm}$. It was observed that the addition of $\left[\mathrm{Cl}^{-}\right]_{\mathrm{o}} \cong 5 \mathrm{ppm}$ polarises significantly the anode potential of oxygen evolution reaction at higher current densities (Figure 3 curve 2); the region between $1.3 \mathrm{~V}$ and $1.5 \mathrm{~V}$ shows the probable occurrence of chlorine evolution that is not observed in curve 1. Further increase in $\left[\mathrm{Cl}^{-}\right]_{\mathrm{o}}$ to $50 \mathrm{ppm}$ and 100 ppm (Figure 3 curves 3 and 4 ) increases the polarisation of oxygen evolution reaction.

3.5. Current Efficiency and Power Consumption. The effect of added chloride ion in the absence and the presence of $\left[\mathrm{Co}^{2+}\right]_{\mathrm{o}}$ on current efficiency and the corresponding power consumption are examined. It was found that the current efficiency remained $\sim 98 \%$ for all additions of chloride ion and/or cobalt ion throughout the investigation, and the cathode remains smooth, bright, and compact. It is seen from Table 1 that the addition of $\left[\mathrm{Cl}^{-}\right]_{\mathrm{o}}$ in the range of 5-100 ppm in the presence of $\mathrm{Co}^{2+}(\mathrm{aq})$ shows increases in the power consumption by $\leq 35 \mathrm{kWh} /$ ton of $\mathrm{Cu}$ than that observed in the presence of only $\left[\mathrm{Co}^{2+}\right]_{0} \cong 150 \mathrm{ppm}$ in the electrolyte solution.

3.6. Crystallographic Orientations. The electrodeposited copper samples produced from acidic copper bath electrolyte solution on stainless steel cathode in the presence of added $\mathrm{Co}^{2+}$ (aq) and/or $\mathrm{Cl}^{-}$(aq) are examined by XRD to determine the preferred crystal orientations and the relative growth of copper on the preferred planes. Representative XRD traces are redrawn and shown in Figure 4. The XRD of all the copper deposits showed an fcc structure, with the $2 \theta$ positions of the peaks remaining constant. The XRD trace for the original 


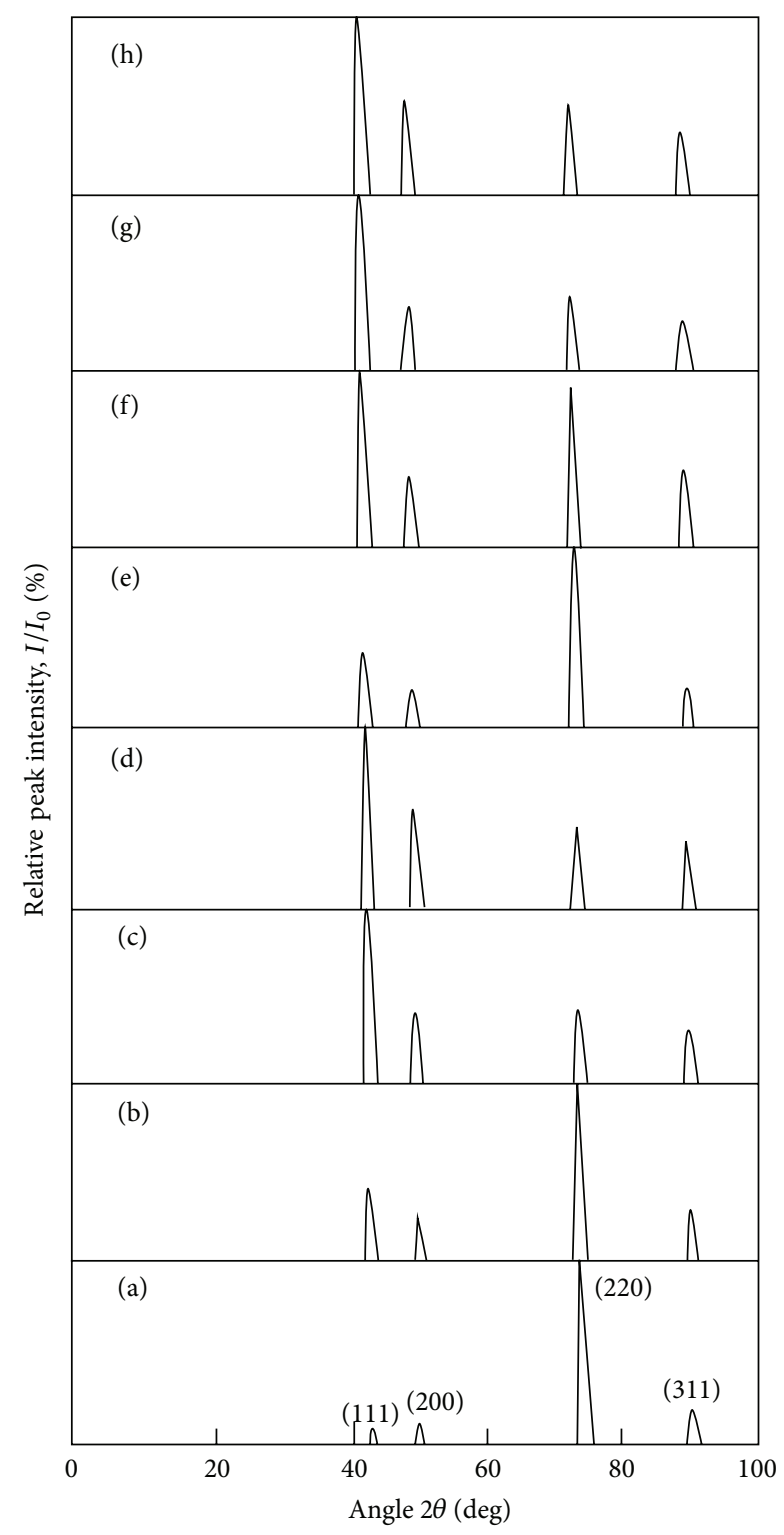

FIGURE 4: XRD patterns of electrodeposited copper samples. Key: added $\left[\mathrm{Co}^{2+}\right]_{0} X \mathrm{ppm}+\left[\mathrm{Cl}^{-}\right]_{\mathrm{o}} \quad Y$ ppm (a) Bl; (b) $0+5 \mathrm{ppm}$; (c) $0+100 \mathrm{ppm}$; (d) $150 \mathrm{ppm}+0$; (e) $150 \mathrm{ppm}+5 \mathrm{ppm}$; (f) $150 \mathrm{ppm}$ + 10 ppm; (g) $150 \mathrm{ppm}+50 \mathrm{ppm}$; (h) $150 \mathrm{ppm}+100 \mathrm{ppm} .\left(\mathrm{Cu}^{2+}=\right.$ $\left.20 \mathrm{~g} / \mathrm{L}, \mathrm{H}_{2} \mathrm{SO}_{4}=30 \mathrm{~g} / \mathrm{L}, \mathrm{T}=30 \pm 1^{\circ} \mathrm{C}, \mathrm{CD}=150 \mathrm{~A} / \mathrm{m}^{2}, t_{d}=2 \mathrm{hr}\right)$.

electrolyte (Figure 4(a)) in the absence of added $\mathrm{Cl}^{-}$and $\mathrm{Co}^{2+}$ (aq) and in the presence of $\left[\mathrm{Co}^{2+}\right]_{\mathrm{o}} \cong 150 \mathrm{ppm}$ (Figure 4(d)) has been given here for comparison. The addition of only $\left[\mathrm{Cl}^{-}\right]_{\mathrm{o}} \cong 5 \mathrm{ppm}$ or $100 \mathrm{ppm}$ changes the XRD pattern of copper deposit differently; while the presence of the former did not alter the most preferred (220) plane (in comparison to Figure 4(a)), the presence of the latter changes the most preferred (220) plane to (111) plane, and the growth along (200), (220), and (311) planes is more or less equally maintained (Figure 4(c)) and is similar in nature with that observed in the presence of only $\left[\mathrm{Co}^{2+}\right]_{0} \cong 150 \mathrm{ppm}$ (Figure $4(\mathrm{~d})$ ). The
TABLE 1: Effect of chloride ion on power consumption in the presence of cobalt ion.

\begin{tabular}{lcc}
\hline$\left[\mathrm{Co}^{2+}(\mathrm{aq})\right]_{\mathrm{o}}, \mathrm{ppm}$ & {$\left[\mathrm{Cl}^{-}\right]_{\mathrm{o}}, \mathrm{ppm}$} & $E, \mathrm{kWh} /$ ton of $\mathrm{Cu}$ \\
\hline 150 & - & 1564 \\
150 & 5 & 1599 \\
150 & 10 & 1599 \\
150 & 50 & 1599 \\
150 & 100 & 1599 \\
\hline
\end{tabular}

$(-)$ refers to nil.

addition of small $\left[\mathrm{Cl}^{-}\right]_{\mathrm{o}} \cong 5 \mathrm{ppm}$ to the electrolyte containing $\left[\mathrm{Co}^{2+}\right]_{0} \cong 150 \mathrm{ppm}$ again retains the most preferred (220) plane (Figure 4(e)); the increase in $\left[\mathrm{Cl}^{-}\right]_{0}$ to $10 \mathrm{ppm}$ in the same electrolyte increases equal growth along (111) and (220) planes (Figure 4(f), further increase in the $\left[\mathrm{Cl}^{-}\right]_{\mathrm{o}} \cong 50 \mathrm{ppm}$ and $100 \mathrm{ppm}$ in the presence of $\left[\mathrm{Co}^{2+}\right]_{\mathrm{o}} \cong 150 \mathrm{ppm}$ retained the (111) plane as the most preferred plane, and the growth along (200), (220), and (311) planes is more or less equally maintained (Figures $4(\mathrm{~g})$ and $4(\mathrm{~h})$ ).

3.7. Surface Morphology. The effect of chloride ion on the surface morphology of the deposited copper samples in the absence and the presence of $\mathrm{Co}^{2+}(\mathrm{aq})$ is shown in Figures $5(\mathrm{a})-5(\mathrm{f})$. It is observed that polycrystalline pyramidal deposits are obtained in the presence of only $\left[\mathrm{Cl}^{-}\right]_{\mathrm{o}} \cong 5 \mathrm{ppm}$ and $\cong 100 \mathrm{ppm}$ in the copper electrolyte solution (Figures 5(a) and $5(\mathrm{~b}))$. The addition of $\left[\mathrm{Cl}^{-}\right]_{0}, 5 \mathrm{ppm}$ to the electrolyte solution containing $\left[\mathrm{Co}^{2+}\right]_{0}, 150 \mathrm{ppm}$ results in very small grains of copper deposits (Figure 5(c)). Increasing the $\left[\mathrm{Cl}^{-}\right]_{\mathrm{o}}$ to $100 \mathrm{ppm}$ in the same electrolyte solution forms small size nodules and mosaic copper deposits (Figures 5(d)-5(f)).

\section{Interpretation}

It would be interesting to interpret the effects of $\mathrm{Cl}^{-}$on electrodeposition of copper in the presence of $\mathrm{Co}^{2+}$ ion. The addition of only $\mathrm{Co}^{2+}$ ion to the copper electrolyte decreases the anode potential significantly but has no effect on the cathode potential as was found in our earlier investigation [12].

The decrease in anode potential in the presence of only $\mathrm{Co}^{2+}$ ion can be best explained by the following reactions. In the absence of $\mathrm{Co}^{2+}$ ion, oxygen is evolved from the electrolysis of water (1) taking place on $\mathrm{PbO}_{2}$ surface on $\mathrm{Pb}$ $\mathrm{Sb}$ anode which exhibits a high overpotential of $\geq 600 \mathrm{mV}$ [1]:

$$
\begin{gathered}
2 \mathrm{H}_{2} \mathrm{O} \longrightarrow \mathrm{O}_{2} \uparrow+4 \mathrm{H}^{+}+4 \mathrm{e} \quad E_{\mathrm{SHE}}=-1.229 \mathrm{~V} \\
\mathrm{Co}^{2+} \longrightarrow \mathrm{Co}^{3+}+\mathrm{e} \quad E_{\mathrm{SHE}}=-1.84 \mathrm{~V} \\
\mathrm{Co}^{3+}+2 \mathrm{H}_{2} \mathrm{O} \longrightarrow 4 \mathrm{Co}^{2+}+4 \mathrm{H}^{+}+\mathrm{O}_{2}
\end{gathered}
$$

While in the presence of only $\mathrm{Co}^{2+}$ ion, oxidation of $\mathrm{Co}^{2+}$ ion to $\mathrm{Co}^{3+}$ ion (2) allows the facile oxidation of $\mathrm{H}_{2} \mathrm{O}$ in accordance with (3) and leads to lower oxygen overpotential $[10,21]$. 

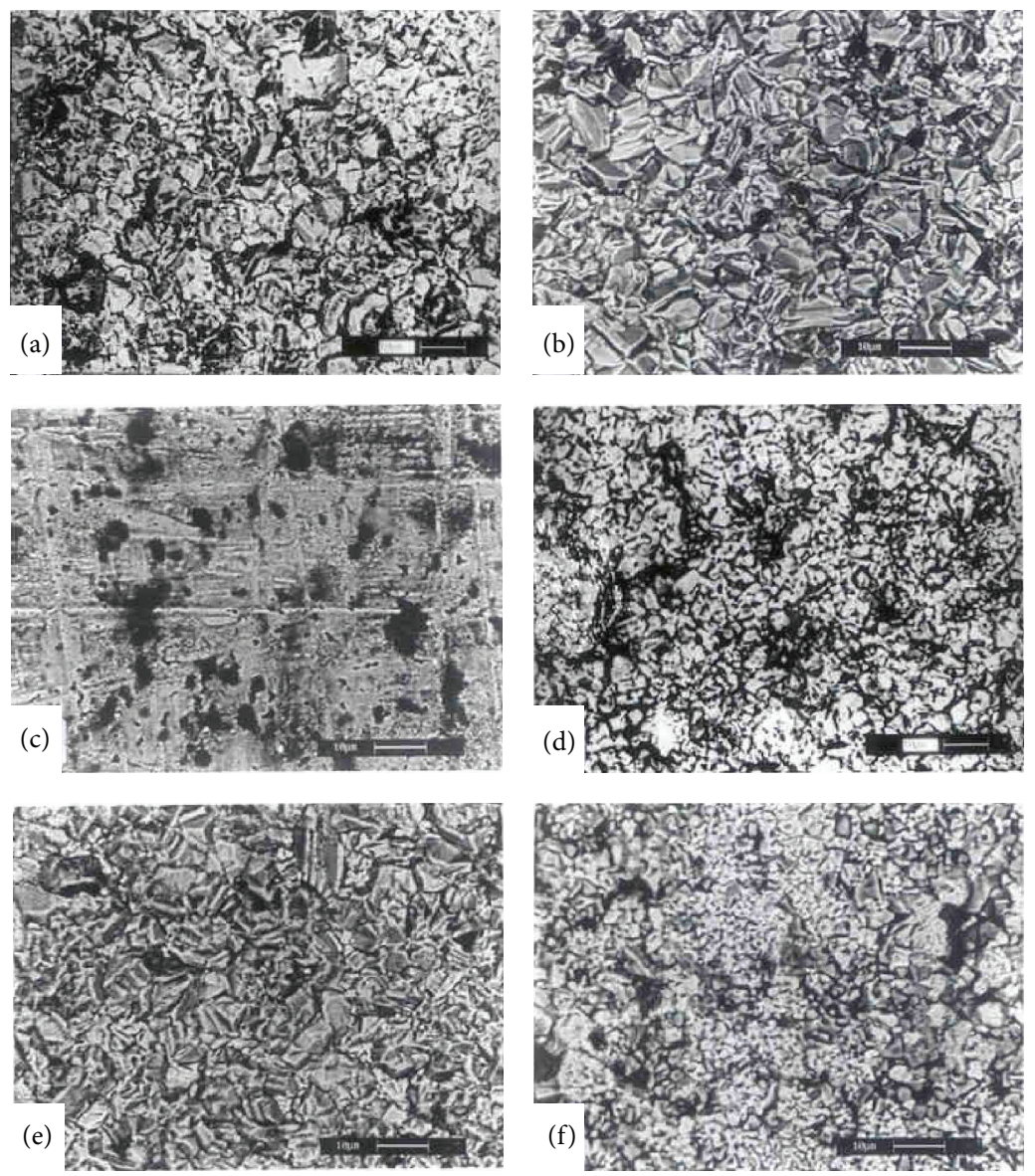

FIGURE 5: SEM photomicrographs of electrodeposited copper samples. Key: added $\left[\mathrm{Co}^{2+}\right]_{\mathrm{o}} X \mathrm{ppm}+\left[\mathrm{Cl}^{-}\right]_{\mathrm{o}} Y \mathrm{ppm}(\mathrm{a}) 0+5 \mathrm{ppm}$; (b) 0 $+100 \mathrm{ppm}$; (c) $150 \mathrm{ppm}+5 \mathrm{ppm}$; (d) $150 \mathrm{ppm}+10 \mathrm{ppm}$; (e) $150 \mathrm{ppm}+50 \mathrm{ppm}$; (f) $150 \mathrm{ppm}+100 \mathrm{ppm}\left(\mathrm{Cu}^{2+}=20 \mathrm{~g} / \mathrm{L}, \mathrm{H}_{2} \mathrm{SO} \mathrm{O}_{4}=30 \mathrm{~g} / \mathrm{L}\right.$, $\left.T=30 \pm 1^{\circ} \mathrm{C}, \mathrm{CD}=150 \mathrm{~A} / \mathrm{m}^{2}, t_{d}=2 \mathrm{hr}\right)$.

An important result found in the present investigation is the increase in the anode potential when a small enough $\left[\mathrm{Cl}^{-}\right]_{0} \cong 5-100 \mathrm{ppm}$ is added to the electrolyte containing $150 \mathrm{ppm} \mathrm{Co}^{2+}(\mathrm{aq})$; nearly $50 \mathrm{mV}$ increase in the anode potential is observed. The same is also indicated in the anodic potentiodynamic study; the addition of $\mathrm{Cl}^{-}$ion to the copper electrolyte is found to polarise the facile oxidation of $\mathrm{H}_{2} \mathrm{O}$ molecules in the presence of $\mathrm{Co}^{2+}$ ion. Thus, the increase in anode voltage due to the presence of $\mathrm{Cl}^{-}$in the copper electrolyte containing $\mathrm{Co}^{2+}$ ion is most probably due to the partial discharge of $\mathrm{Cl}^{-}$ion at the anode as given in $(4)[21,22]$ as well as the polarisation of the facile oxidation of $\mathrm{H}_{2} \mathrm{O}$ molecules as described in (2) and (3) due to the $\mathrm{Cl}^{-}$ions. Indication for this interpretation is the observed evolution of $\mathrm{Cl}_{2}(\mathrm{~g})$ at the anode during the experimental work:

$$
2 \mathrm{Cl}^{-} \longrightarrow \mathrm{Cl}_{2}+2 \mathrm{e} \quad E_{\mathrm{SHE}}^{\phi}=-1.35 \mathrm{~V}
$$

The decrease in the cathode potential in the presence of $\mathrm{Cl}^{-}$ion may be due to the ready discharge of the $\mathrm{Cu}^{2+}-\mathrm{Cl}^{-}$ complex at the cathode [23].

\section{Conclusions}

The results observed in the present investigation can be summarised as follows.

(1) The addition of $5 \mathrm{ppm}$ of chloride ion to the copper electrolyte solution in the presence of $150 \mathrm{ppm} \mathrm{Co}^{2+}$ ion increased the anode potential by $\cong 50 \mathrm{mV}$ which is more or less maintained with further increase in $\mathrm{Cl}^{-}$ion concentration up to $100 \mathrm{ppm}$. The increase in the chloride ion concentration (in the range of $0-100 \mathrm{ppm}$ ) in the electrolyte solution decreases the cathode potential in the presence of $\mathrm{Co}^{2+} \cong 150 \mathrm{ppm}$ from $0.25 \mathrm{~V}$ to $0.19 \mathrm{~V}$.

(2) The addition of $\cong 0-100 \mathrm{ppm}$ of $\mathrm{Cl}^{-}$to the electrolyte solution containing $150 \mathrm{ppm} \mathrm{Co}^{2+}$ increases the power consumption by $35 \mathrm{kWh} /$ ton $\mathrm{Cu}$.

(3) The increase in the chloride ion concentration in the absence and the presence of cobaltous ion changes the most preferred (220) hkl plane to (111) hkl plane. 
(4) No significant change in the surface morphology of the copper deposits is observed. Smooth, bright deposits are obtained throughout the investigation.

\section{Abbreviations}

$\begin{array}{ll}E_{\mathrm{a}}: & \text { Anode potential } \\ E_{\mathrm{cell}}: & \text { Cell potential } \\ E(\mathrm{kWh} / \text { ton } \mathrm{Cu}): & \text { Energy consumption } \\ {[\mathrm{Cl}]_{\mathrm{o}}:} & \text { Initial concentration of } \mathrm{Cl}^{-} \text {ion } \\ {\left[\mathrm{Co}^{2+}\right]_{\mathrm{o}}:} & \text { Initial concentration of } \mathrm{Co}^{2+} \text { ion } \\ \mathrm{CD}: & \text { Current density } \\ T_{\mathrm{d}}: & \text { Electrolysis duration } \\ T: & \text { Temperature. }\end{array}$

\section{Acknowledgment}

The author is thankful to Dr. R. K. Panda for his encouragement during the investigation and preparation of the paper.

\section{References}

[1] A. K. Biswas and W. G. Davenport, Extractive Metallurgy of Copper, Pergamon Press, Oxford, UK, 1976.

[2] K. K. Mishra and W. C. Cooper, "Anodes for electrowinning," in Proceedings of the AIME Annual Meeting, Los Angeles, D. J. Robinson and S. E. James, Eds., pp. 13-36, Metallurgical Society of AIME, Warrendale, Pa, USA, 1984.

[3] T. Subbaiah, P. Singh, G. Hefter, D. Muir, and R. P. Das, "Sulphurous acid as anodic depolarizer in copper electrowinningpart II," Journal of Applied Electrochemistry, vol. 30, no. 2, pp. 181-186, 2000.

[4] B. Panda and S. C. Das, "Electrowinning of copper from sulfate electrolyte in presence of sulfurous acid," Hydrometallurgy, vol. 59, no. 1, pp. 55-67, 2001.

[5] B. Panda, S. C. Das, and R. K. Panda, "Synergistic effects of added bivalent aqua cobalt ion, bivalent aqua iron ion and aqueous sulfurous acid on a graphite anode during electrodeposition of copper from a sulfate bath," Hydrometallurgy, vol. 72, no. 1-2, pp. 149-158, 2004.

[6] B. Panda, S. C. Das, and R. K. Panda, "Cathodic deposition of copper in the presence of aqueous sulfurous acid, bivalent aquacobalt ion, or both using a stainless steel cathode and a graphite anode," Metallurgical and Materials Transactions B, vol. 34, no. 6, pp. 813-819, 2003.

[7] W. C. Cooper, "Advances and future prospects in copper electrowinning," Journal of Applied Electrochemistry, vol. 15, pp. 789-805, 1985.

[8] D. Pletcher and F. C. Walsh, Industrial Electrochemistry, Chapman \& Hall, London, UK, 1990.

[9] R. D. Armstrong, M. Todd, J. W. Atkinson, and K. Scott, "Selective electrodeposition of metals from simulated waste solutions," Journal of Applied Electrochemistry, vol. 26, no. 4, pp. 379-384, 1996.

[10] A. S. Gendron, A. V. Enel, and S. Abe, "Effect of cobalt added to electrolyteon corrosion rate of $\mathrm{Pb}-\mathrm{Sb}$ anodes in copper electrowinning," Canadian Metallurgical Quarterly, vol. 14, pp. 59-62, 1975.

[11] C. Lupi and D. Pilone, "Energy saving in copper electrowinning," in Aqueous Electrotechnology: Progress in Theory and Practice, D. B. Dreisinger, Ed., TMS, Warrendale, Pa, USA, 1997.
[12] B. Panda, S. C. Das, and R. K. Panda, "Effect of added cobalt ion on electro-deposition of copper from sulfate bath using graphite and $\mathrm{Pb}-\mathrm{Sb}$ anodes," Hydrometallurgy, vol. 95, no. 1-2, pp. 87-91, 2009.

[13] Z. D. Stanković, "The effect of $\mathrm{Cl}(\mathrm{I})^{-}$ions on kinetics and mechanism of anodic dissolution and cathodic deposition of copper," Electrochimica Acta, vol. 29, no. 3, pp. 407-409, 1984.

[14] I. J. Itzkovitch, V. A. Ettel, and A. S. Gendron, "Copper removal from thompson nickel anolyte by solvent extraction," Canadian Mining and Metallurgical Bulletin, vol. 67, no. 741, pp. 92-96, 1974.

[15] N. Pradhan, P. G. Krishna, and S. C. Das, "Influence of chloride ion on electrocrystallization of copper," Plating and Surface Finishing, vol. 83, no. 3, pp. 56-63, 1996.

[16] V. I. Lakshmanan, D. J. Mackinnon, and J. M. Brannen, "The effect of chloride ion in the electrowinning of copper," Journal of Applied Electrochemistry, vol. 7, no. 1, pp. 81-90, 1977.

[17] E. Ilgar and T. J. O’Keefe, "Surface roughening of electrowon copper in the presence of chloride ions," in Aqueous Electrotechnology: Progress in Theory and Practice, D. B. Dreisinger, Ed., The Minerals, Metals and Materials Society, 1997.

[18] T. C. Franklin, "Some mechanisms of action of additives in electrodeposition processes," Surface and Coatings Technology, vol. 30, no. 4, pp. 415-428, 1987.

[19] G. Fabricius and G. Sundholm, "The effect of additives on the electrodeposition of copper studied by the impedance technique," Journal of Applied Electrochemistry, vol. 14, no. 6, pp. 797-801, 1984.

[20] V. I. Lakshmanan, D. J. Mackinnon, and J. M. Brannen, “The effect of thiourea, LIX65N and chloride ion on the morphology of electrowon copper," Journal of Applied Electrochemistry, vol. 7, no. 2, pp. 127-133, 1977.

[21] "Max absorption (GAS): $162 \mathrm{NM}$ shoulder (LOG $\mathrm{E}=4.0$ ); $175 \mathrm{NM}$ (LOG E = 4.2); $187 \mathrm{NM}(\mathrm{LOG} \mathrm{E}=4.1)$," in CRC Handbook of Chemistry and Physics, R. C. Weast and M. J. Astle, Eds., p. C-229, Boca Ranton, Fla, USA, 60th edition, 1979-1980.

[22] G. Milazza and S. Caroli, Table of Standard Electrode Potentials, Project of the IUPAC Electrochemistry Commission, John Wiley and Sons, 1978.

[23] A. J. Sukava and C. A. Winkler, "Depolarization by mercaptoacetic acid during electrodeposition of copper," Canadian Journal of Chemistry, vol. 34, pp. 128-132, 1956. 

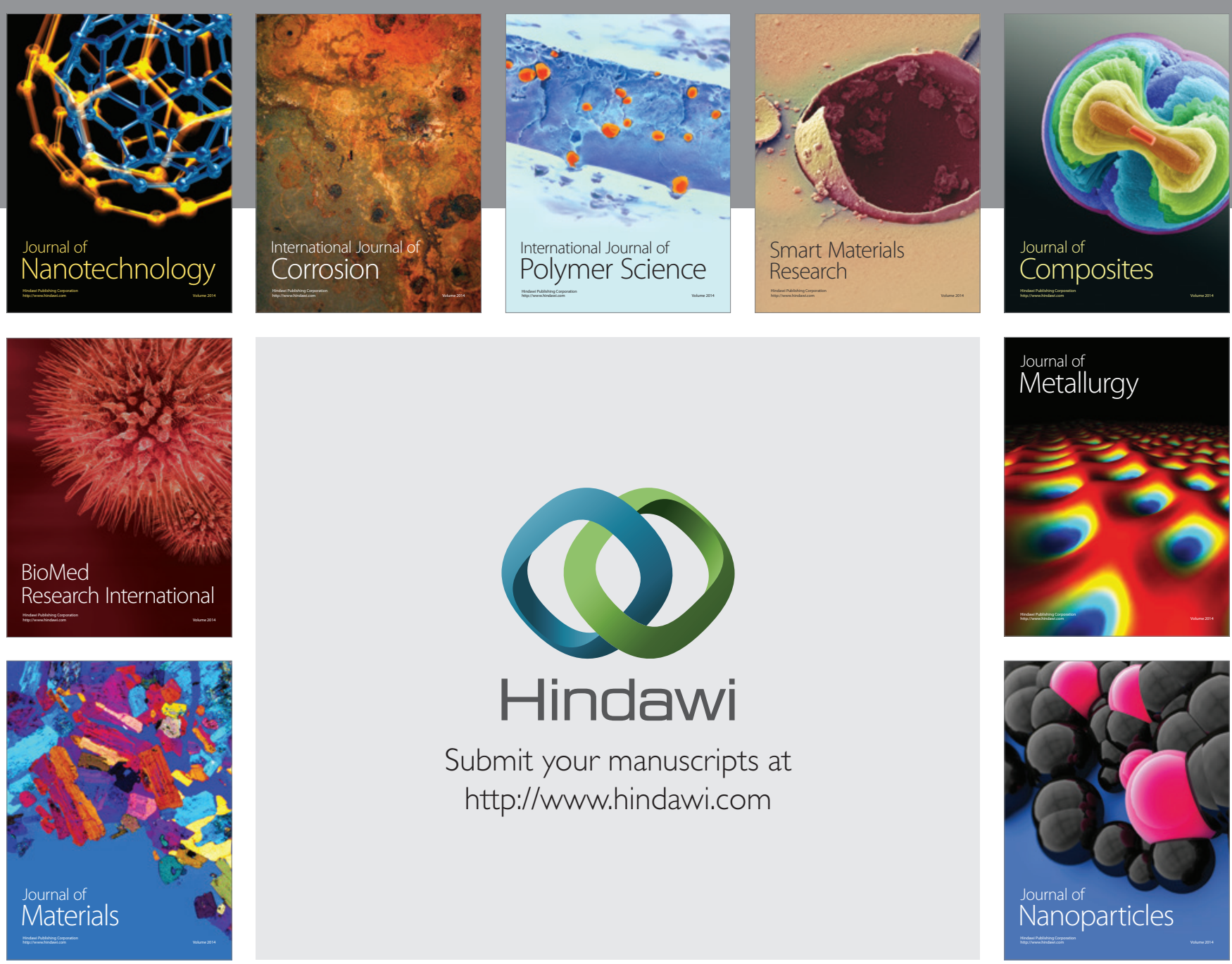

Submit your manuscripts at http://www.hindawi.com
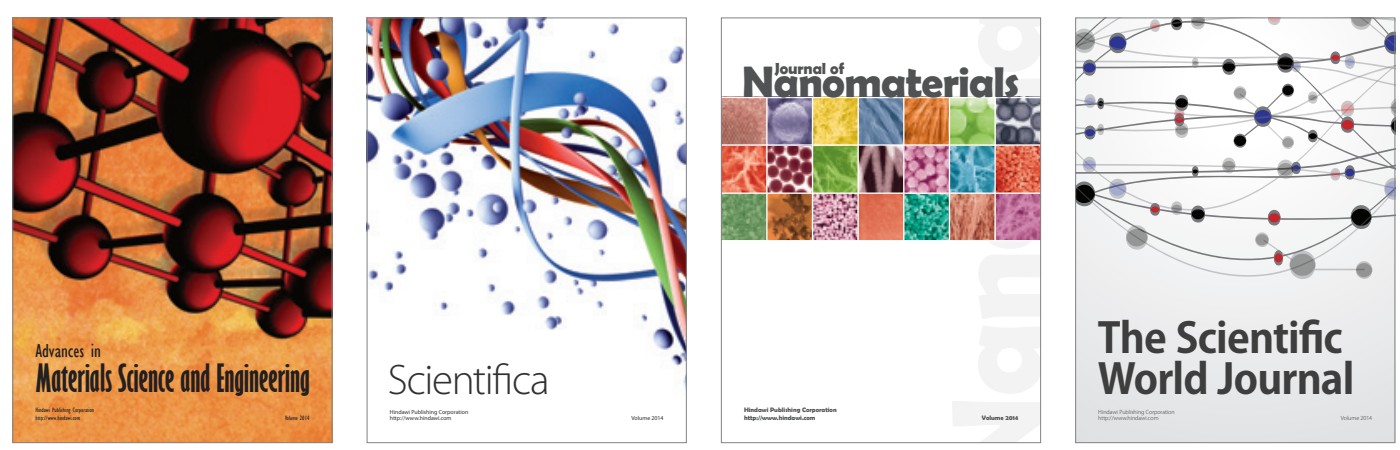

\section{The Scientific World Journal}
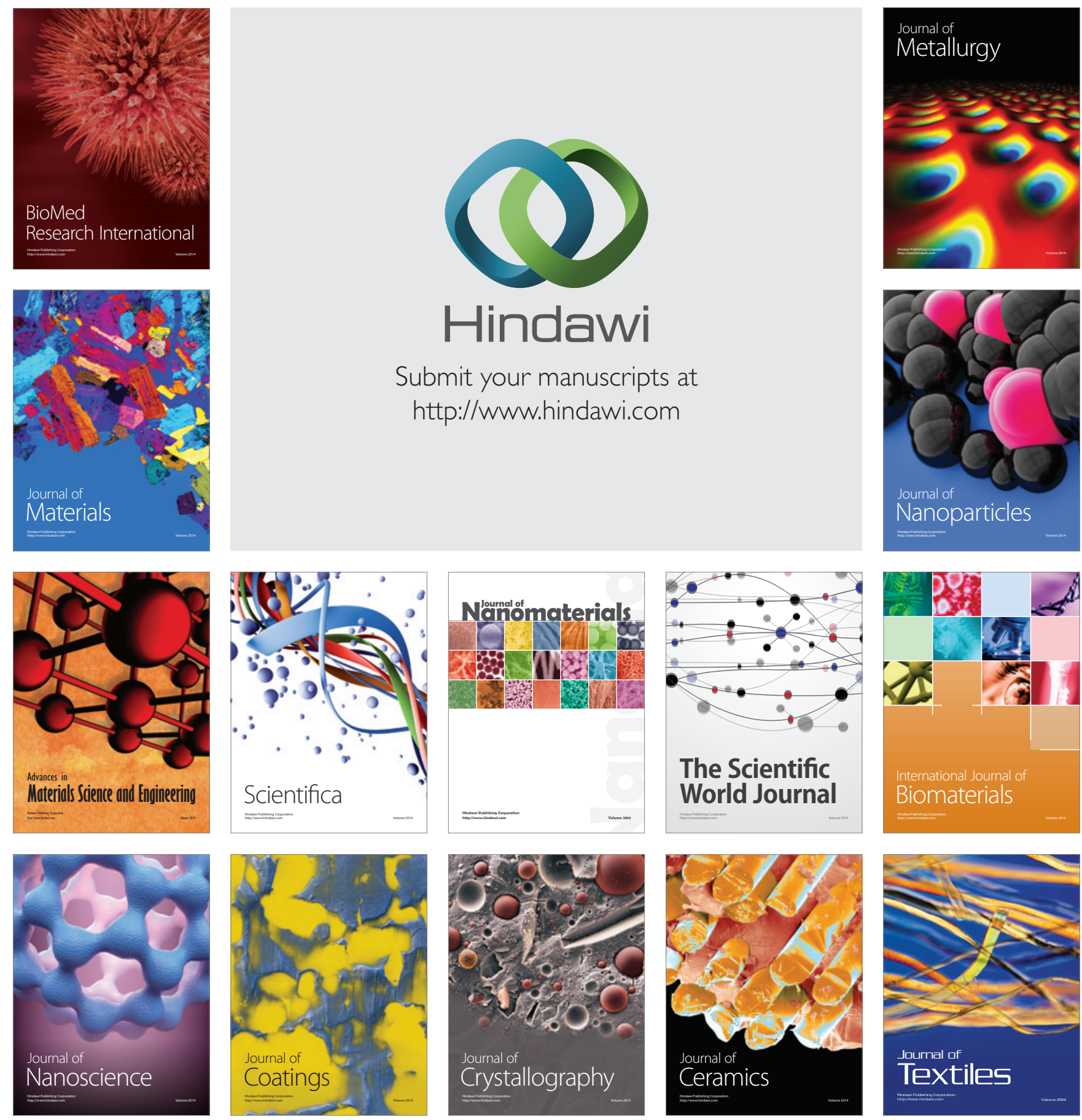